Jurnal ABDINUS : Jurnal Pengabdian Nusantara, 3 (1), 2019, 73-82

Available online at: http://ojs.unpkediri.ac.id/index.php/PPM

DOI: $\underline{\text { https://doi.org/10.29407/ja.v3i1.12701 }}$

\title{
Peningkatan Perekonomian Kelompok Wanita Kelurahan Tanjung Selamat Kabupaten Deli Serdang Melalui Pengembangan Produk Berbahan Dasar Ikan
}

\author{
Dwi Tika Afriani ${ }^{1}$, Emmy Syafitri $^{2 *}$, Mekar Meilisa Amalia ${ }^{3}$ \\ 2esyafitri@dharmawangsa.ac.id \\ ${ }^{1,2}$ Program Studi Budidaya Perairan \\ ${ }^{3}$ Program Studi Akuntansi \\ ${ }^{1,2}$ Fakultas Perikanan \\ ${ }^{3}$ Fakultas Ekonomi \\ ${ }^{1,2,3}$ Universitas Dharmawangsa
}

Received: 3101 2019. Revised: 1904 2019. Accepted: 28082019

\begin{abstract}
Community partnership program in Tanjung Selamat Village, Deli Serdang Regency, North Sumatra is motivated by the economic life of some housewives which are in the middle to lower class of economic life. The purpose of this training is to help the problems from the partnership through improving the economic life and family standard living by making a fish sauce. The methods of activities carried out to achieve the objectives of community partnership are: (1) lecture method; (2) discussion method, and (3) practical demonstration method. The practical demonstration method is carried out by training all service participants through the practice of making fish sauce directly to the group of housewives. The results of the activities that have been carried out are the increase in knowledge and skills of housewives in the diversification of processing fisheries food so that they are expected to contribute to improving the family economy.
\end{abstract}

Keywords: Tanjung Selamat Village, Fish sauce, Housewife

Abstrak: Pengabdian masyarakat di Desa Tanjung Selamat Kabupaten Deli Serdang SUMUT ini dilatarbelakangi kehidupan perekonomian sebagian ibu-ibu rumah tangga di wilayah tersebut berada pada golongan ekonomi menengah ke bawah. Kegiatan pelatihan pembuatan kecap ikan menjadi tujuan kami dalam membantu mengatasi permasalahan ini dengan peningkatan nilai ekonomi dan taraf hidup keluarga. Metode kegiatan yang dilakukan untuk tercapainya tujuan pengabdian kepada masyarakat ini adalah: (1) metode ceramah; (2) metode diskusi, dan (3) metode demonstrasi praktik. Metode demonstrasi praktik dilakukan dengan cara melatih seluruh peserta pengabdian melalui praktik pembuatan kecap ikan secara langsung ke kelompok ibu-ibu rumah tangga tersebut. Hasil kegiatan yang telah dilakukan adalah terjadinya peningkatan pengetahuan dan ketrampilan ibu-ibu rumah tangga dalam diversifikasi pengolahan bahan pangan perikanan sehingga diharapkan dapat memberikan kontribusi dalam peningkatkan perekonomian keluarga.

Kata kunci: Desa Tanjung Selamat, kecap ikan, ibu rumah tangga. 


\section{ANALISIS SITUASI}

Kelompok wanita Desa Tanjung Selamat Kecamatan Sunggal Deli Serdang yang termasuk di dalamnya adalah kelompok ibu-ibu rumah tangga yang sebagian besar bekerja sebagai pembantu rumah tangga pada tetangganya atau di perumahan-perumahan mewah pada wilayah kelurahan lain dan biasanya setelah waktu ashar mereka baru pulang. Cukup sulitnya membangun ekonomi bagi ibu-ibu rumah tangga yang sebagian besar selalu bergantung pada orang lain, bekerja sebagai pembantu rumah tangga, atau hanya berdagang kecil-kecilan membuat mereka cukup sulit untuk menyekolahkan anak-anak mereka hingga ke perguruan tinggi.

Ikan merupakan salah satu komoditi pangan yang mudah rusak dan menjadi busuk karena kadar airnya yang tinggi dan kandungan gizinya yang baik untuk pertumbuhan jasad renik pembusuk. Upaya untuk mengatasi sifat mudah busuk tersebut, antara lain dengan cara pengawetan. Selain melalui proses pengawetan, komoditi ikan hasil tangkapan berpotensi untuk ditingkatkan nilai tambahnya melalui proses pengolahan. Proses pengolahan juga dimaksudkan untuk memanfaatkan kelebihan pasokan (volume hasil tangkapan) yang tidak terserap oleh pasar baik untuk konsumsi ikan segar, industri pengolahan ikan, dan ekspor (Ma'ruf et al. 2015).

Pengolahan ikan secara tradisional antara lain adalah pengasapan, pemindangan dan fermentasi. Salah satu bentuk upaya pengolahan ikan secara fermentasi adalah diolah menjadi kecap ikan. Secara terminologi teknologi, kecap ikan merupakan hasil penguraian secara biologis melalui proses fermentasi terhadap senyawa-senyawa kompleks terutama protein menjadi senyawa-senyawa yang lebih sederhana dalam keadaan terkontrol (Siswi Astuti, Eko Edy Susanto 2015). Berdasarkan Standar Nasional Indonesia (SNI), kecap ikan didefinisikan sebagai produk cair yang diperoleh dengan hidrolisis ikan dengan atau tanpa penambahan bahan makan lain dan bahan tambahan makanan yang diizinkan (DKBU 2011). Sebagai produk pangan, kecap termasuk bumbu makanan berbentuk cair, berwarna coklat kehitaman, serta memiliki rasa dan aroma ikan yang khas.

Rencana kajian yang akan disajikan pada kegiatan pengabdian kali ini adalah kecap ikan yang diolah bukan melalui proses hidrolisis protein ikan, akan tetapi suatu produk cair yang kental yang diperoleh dengan cara perebusan ikan dengan bumbu tertentu, yang setelah disaring kemudian dimasak dalam larutan gula aren. Diversifikasi cara pengolahan produk bahan pangan ini merupakan inovasi pemanfaatan ikan segar oleh pengrajin di Kota Ternate untuk meningkatkan nilai tambah hasil tangkapan yang dilakukan dengan menggunakan 


\section{Jurnal ABDINUS : Jurnal Pengabdian Nusantara, 3 (1), 2019, 73-82 \\ Dwi Tika Afriani, Emmy Syafitri, Mekar Meilisa Amalia}

teknologi yang sederhana yang diusahakan dalam skala industri rumah tangga. Metode ini perlu disosialisasikan sehingga dalam pembuatan kecap ikan menjadi lebih efektif dan efisien.

Berdasarkan permasalahan dan informasi di atas, ibu-ibu rumah tangga di daerah ini perlu dididik untuk belajar berwirausaha dengan menambahkan ketrampilan membuat olahan bahan pangan ikan yang mempunyai daya jual tinggi dan dapat meningkatkan perekonomian keluarga.

\section{SOLUSI DAN TARGET}

Kecap ikan merupakan olahan ikan yang memiliki kandungan gizi tinggi, tidak memerlukan dana dan tenaga yang cukup besar sehingga gampang dilakukan oleh pemula sekalipun. Oleh karena itu, kami selaku tim pengabdi Universitas Dharmawangsa berkeinginan ibu-ibu rumah tangga di wilayah ini memulai berwirausaha membuat kecap ikan dan membangkitkan kepercayaan diri para ibu-ibu rumah tangga Tanjung Selamat dan berharap setelah mengikuti pelatihan ini akan merangsang wawasan ibu-ibu rumah tangga Tanjung Selamat untuk berwirausaha kecap ikan. Solusi yang ditawarkan untuk menyelesaikan permasalahan yang dihadapi kelompok ibu-ibu rumah tangga Kelurahan Tanjung Selamat adalah : (1) Melakukan pendidikan dan pelatihan baik secara teoritis maupun praktis dengan membuat percontohan dan penerapan teknologi pembuatan kecap ikan; (2) Melakukan evaluasi keberhasilan seluruh program baik secara fisik maupun persepsi.

Target yang akan dihasilkan dari kegiatan pengabdian ini adalah : (1) Menumbuhkan kesadaran dan minat kepada peserta pelatihan dalam mengolah ikan menjadi kecap ikan; (2) Membentuk kelompok-kelompok usaha pengolahan ikan dengan mengembangkan jiwa entrepreneur bagi peserta pelatihan; (3) Memiliki pengetahuan dan keterampilan dalam mengolah ikan menjadi produk yang sehat, menggugah selera, dapat dikonsumsi secara instan, dan memanfaakan menjadi peluang usaha; (4) Target yang diharapkan bagi tim pengusul, Program Pengabdian kepada Masyarakat ini selain sebagai bentuk pelaksanaan Tri Dharma Perguruan Tinggi, juga sebagai bentuk rasa kepedulian kepada pemberdayaan masyarakat.

\section{METODE PELAKSANAAN}

Bahan utama yang digunakan dalam kegiatan ini terdiri dari ikan segar, bumbu dapur (lengkuas, serai, kunyit, jeruk nipis dan gula merah) dan air. Sedangkan alat yang digunakan 
dalam kegiatan ini meliputi peralatan memasak seperti kompor gas, wajan, saringan, dan peralatan pendukung lainnya. Kegiatan ini merupakan bagian dari tridarma perguruan tinggi dan bertanggung jawab kepada masyarakat dalam memecahkan masalah yang berkembang.

Pelaksana pengabdian ini merupakan dosen tetap Universitas Dharmawangsa yang difasilitasi oleh Lembaga Pengabdian kepada Masyarakat Universitas Dharmawangsa. Pengabdian masyakat ini di laksanakan pada hari Sabtu tanggal 24 Desember 2018 dengan sasaran kelompok wanita dari kegiatan pengabdian ini adalah ibu-ibu rumah tangga yang tergabung dalam kelompok pengajian Desa Tanjung Selamat yang masih menganggur dan ingin meningkatkan ketrampilan diri dalam bidang pengolahan produk pangan perikanan. Jumlah sasaran berjumlah 21 orang.

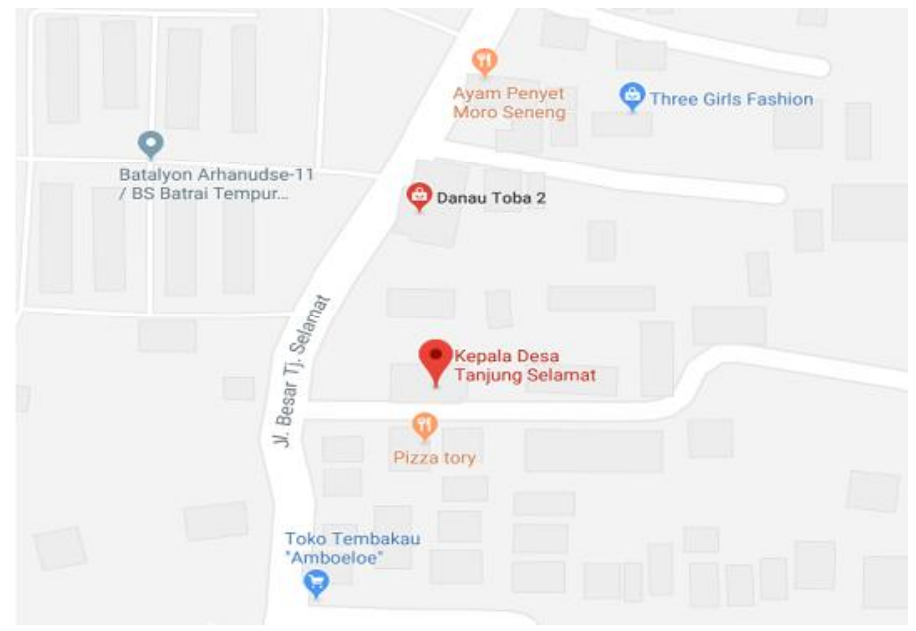

Gambar 1. Peta Lokasi Wilayah Mitra (0) (Sumber : Google map)

Dalam rangka mengembangkan potensi kelompok ibu-ibu dalam mengolah produk lokal serta meningkatkan perekonomian keluarga dan masyarakat, maka dilakukan pemberdayaan berupa pelatihan diversifikasi pengolahan bahan lokal. Adapun langkahlangkah pemecahan masalah adalah sebagai berikut: (1) Penentuan kebutuhan; (2) Penentuan sasaran; (3) Penetapan materi pelatihan; (4) Pelaksanaan program; dan (5) Evaluasi pelaksanaan program. Untuk mendapatkan hasil pelatihan yang maksimal, maka perlu dirancang materi yang akan diberikan meliputi (Tabel 1)

Tabel 1. Materi Pelatihan

\begin{tabular}{|l|l|c|}
\hline \multicolumn{1}{|c|}{ Metode } & \multicolumn{1}{|c|}{ Tujuan } & $\begin{array}{c}\text { Alokasi Waktu } \\
\text { (menit) }\end{array}$ \\
\hline $\begin{array}{l}\text { Ceramah dan } \\
\text { Diskusi }\end{array}$ & $\begin{array}{l}\text { Membangun kesadaran kelompok sasaran akan pentingnya } \\
\text { diversifikasi pengolahan pangan lokal dan memberikan } \\
\text { pengetahuan kepada kelompok sasaran mengenai: } \\
\text { 1. Diversifikasi dan pengembangan produk perikanan; }\end{array}$ & 60 \\
\hline
\end{tabular}


Jurnal ABDINUS : Jurnal Pengabdian Nusantara, 3 (1), 2019, 73-82

Dwi Tika Afriani, Emmy Syafitri, Mekar Meilisa Amalia

\begin{tabular}{|l|l|c|}
\hline & $\begin{array}{l}\text { 2. Cara menentukan harga jual produksi kecap ikan; dan } \\
\text { 3. Materi dan praktek pembuatan kecap ikan dengan cara } \\
\text { pemasakan }\end{array}$ & 150 \\
\hline $\begin{array}{l}\text { Learning by } \\
\text { project }\end{array}$ & $\begin{array}{l}\text { Tutorial pembuatan produk kecap ikan kepada kelompok } \\
\text { wanita Kelurahan Tanjung Selamat }\end{array}$ & 30 \\
\hline $\begin{array}{l}\text { Refleksi dan } \\
\text { Evaluasi }\end{array}$ & $\begin{array}{l}\text { Membangun kesepahaman dan komitmen kelompok sasaran } \\
\text { untuk menerapkan hasil belajar }\end{array}$ & \\
\hline
\end{tabular}

Bentuk keterampilan yang akan dilatihkan kepada ibu-ibu rumah tangga melalui diversifikasi hasil olahan ikan adalah dalam produk kecap ikan. Adapun alur pembuatan kecap berbahan dasar ikan dapat dilihat pada Gambar 2.

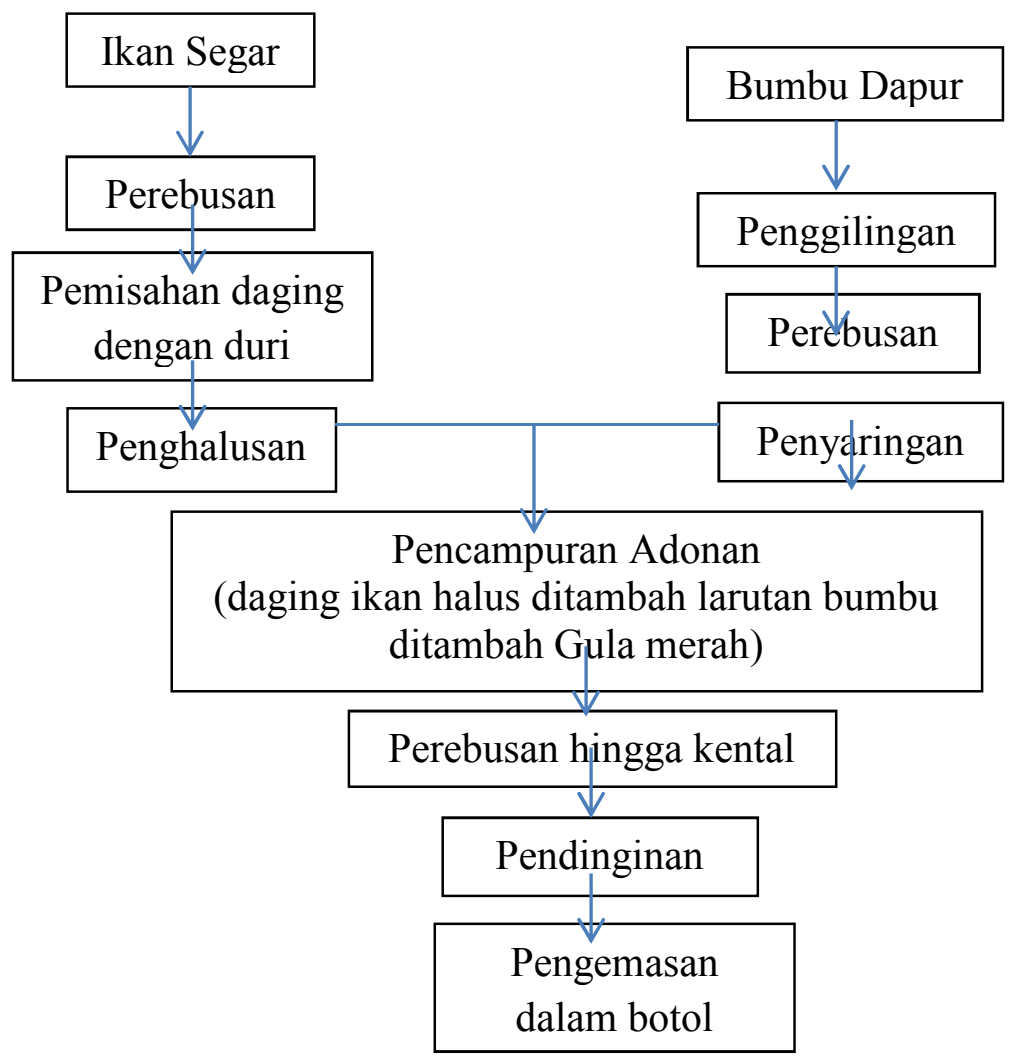

Gambar 2. Alur kegiatan pembuatan kecap ikan

Metode kegiatan yang dilakukan untuk tercapainya tujuan pengabdian kepada masyarakat ini adalah : (1) metode ceramah; digunakan pada saat sesi penyampaian materi, dimana narasumber memberikan materi kepada peserta pelatihan sebelum dilaksanakannya praktek. (2) metode diskusi; digunakan untuk merefleksi materi yang telah disampaikan oleh narasumber, dan (3) metode demonstrasi praktik; bertujuan untuk mempraktekkan materi yang sudah disampaikan oleh narasumber, sehingga ilmu yang diperoleh dapat diaplikasikan dalam kehidupan nyata. Karena pada intinya pelatihan ini adalah praktek secara langsung bagaimana mengolah hasil perikanan menjadi produk jadi yang harapannya dapat memiliki nilai jual lebih tinggi dari sebelumnya. 


\section{HASIL DAN LUARAN}

\section{Realisasi Pemecahan Masalah}

Persiapan yang dilakukan sebelum kegiatan pengabdian masyarakat dilaksanakan adalah dimulai dengan observasi lokasi kegiatan pengabdian kepada masyarakat Desa Tanjung Selamat Kecamatan Sunggal Kabupaten Deli Serdang untuk mendiskusikan strategi pelaksanaan pengabdian di wilayah tersebut. Selanjutnya tim pelaksana pengabdian berkoordinasi dengan LPkM Universitas Dharmawangsa dan perangkat desa terkait koordinasi dan pengurusan izin pelaksanaan kegiatan serta menyepakati tanggal pelaksanaan.

Pada tahap persiapan ini, tim pengabdi melakukan persiapan-persiapan sebagai berikut: (1) melakukan studi pustaka tentang berbagai diversifikasi pengolahan pangan berbahan dasar ikan khususnya kecap ikan; (2) melakukan persiapan alat dan bahan yang berhubungan dengan pembuatan kecap ikan; (3) melakukan uji coba pembuatan produk olahan ikan yaitu kecap ikan sebelum hari pelaksanaan; (4) menentukan waktu pelaksanaan dan lamanya kegiatan pengabdian bersama-sama tim pelaksana; dan (5) menentukan dan mempersiapkan materi yang akan disampaikan dalam kegiatan pengabdian masyarakat.

\section{Hasil Kegiatan Pengabdian}

Hasil dari kegiatan pengabdian kepada masyarakat yang dilaksanakan di desa Tanjung Selamat ini dapat dirinci sebagai berikut :

1. Pelaksanaan kegiatan pengabdian berlangsung pada hari Sabtu, 24 Desember 2018 dengan dihadiri oleh 21 orang peserta di Balai Desa Tanjung Selamat. Kegiatan berupa penyampaian materi dan praktek langsung pembuatan produk olahan ikan yaitu kecap ikan. Peserta dibagi dalam 2 kelompok yang terdiri dari 10 dan 11 orang anggota. Setiap kelompok melakukan praktek langsung setelah diberikan penjelasan materi oleh tim pelaksana. Pelaksanaan kegiatan pengabdian tersebut dibuka secara langsung oleh Kepala Desa Tanjung Selamat, dan dilanjutkan dengan pemaparan materi oleh tim pelaksana pengabdian UNDHAR serta praktek oleh masyarakat mitra (Gambar 3, 4, dan 5). Antusias kelompok ibu-ibu rumah tangga sangat baik terhadap acara tersebut hal ini dapat dilihat bahwa mitra mengikuti kegiatan sampai selesai dan juga respon ibu-ibu dalam berdiskusi dan mengajukan pertanyaan-pertanyaan yang terkait dengan materi dan praktek yang diberikan oleh tim pelaksana sangat baik (Gambar 6). Adapun materi dan praktek yang diberikan dalam kegiatan tersebut antara lain: (1) Diversifikasi dan pengembangan produk perikanan; (2) Cara menentukan harga jual produksi kecap ikan; dan (3) materi dan praktek pembuatan kecap ikan dengan cara pemasakan. 


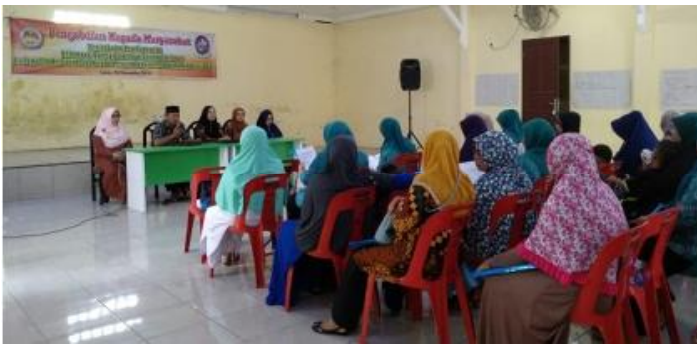

Gambar 3. Kepala Desa membuka acara kegiatan pengabdian masyarakat

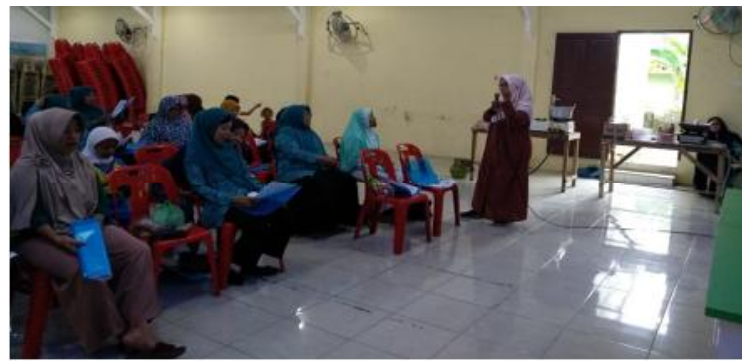

Gambar 5. Penjelasan materi 2 oleh anggota pelaksana

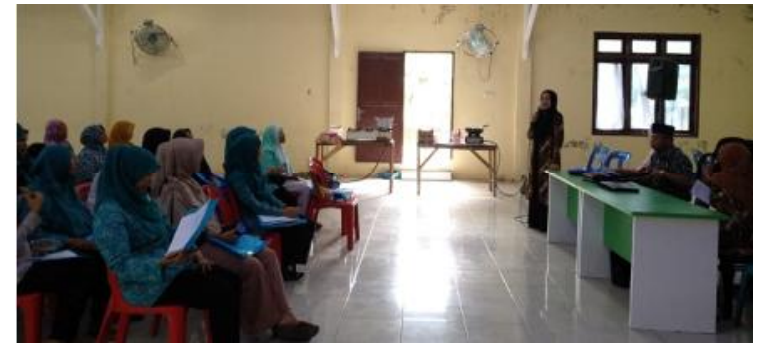

Gambar 4. Penjelasan materi 1 oleh Ketua tim pelaksana

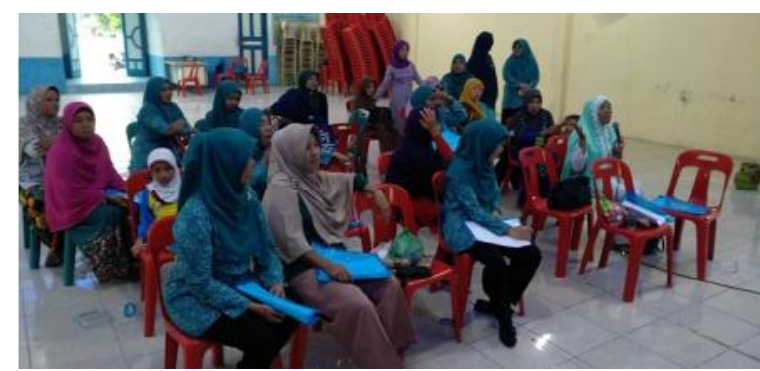

Gambar 6. Acara diskusi, salah satu peserta mengajukan pertanyaan kepada tim pelaksana

2. Setelah ceramah dan diskusi wawasan, tim pelaksana menjelaskan dan mendemonstrasikan bahan-bahan kecap ikan serta cara membuatnya. Selanjutnya peserta diberi kesempatan untuk mempraktekkan langsung per kelompok tentang cara pembuatan kecap ikan. Berdasarkan pengamatan terhadap kemampuan/ketrampilan ibu-ibu peserta pelatihan dalam menerapkan pembuatan kecap ikan terlihat sekitar $90 \%$ dari seluruh masyarakat peserta pelatihan mampu melakukan pembuatan kecap ikan. Adapun praktek pembuatan kecap ikan dan hasilnya selama 1 hari kegiatan pengabdian masyarakat dapat dilihat pada gambar 7 .

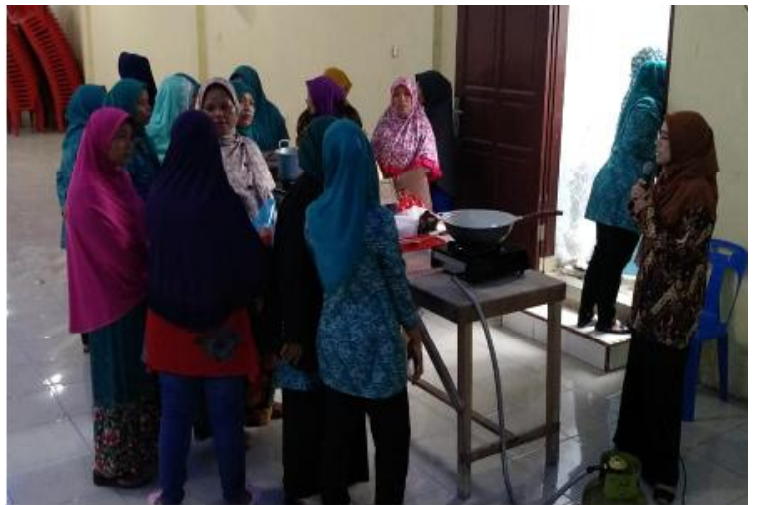

Gambar 7. Demonstrasi pembuatan kecap ikan oleh anggota pelaksana

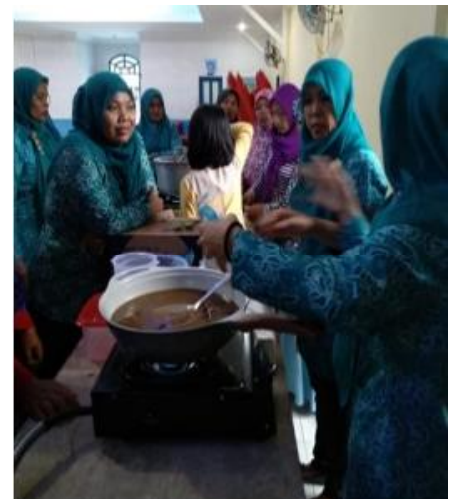

Gambar 8. Praktek langsung oleh ibuibu mitra pengabdian 

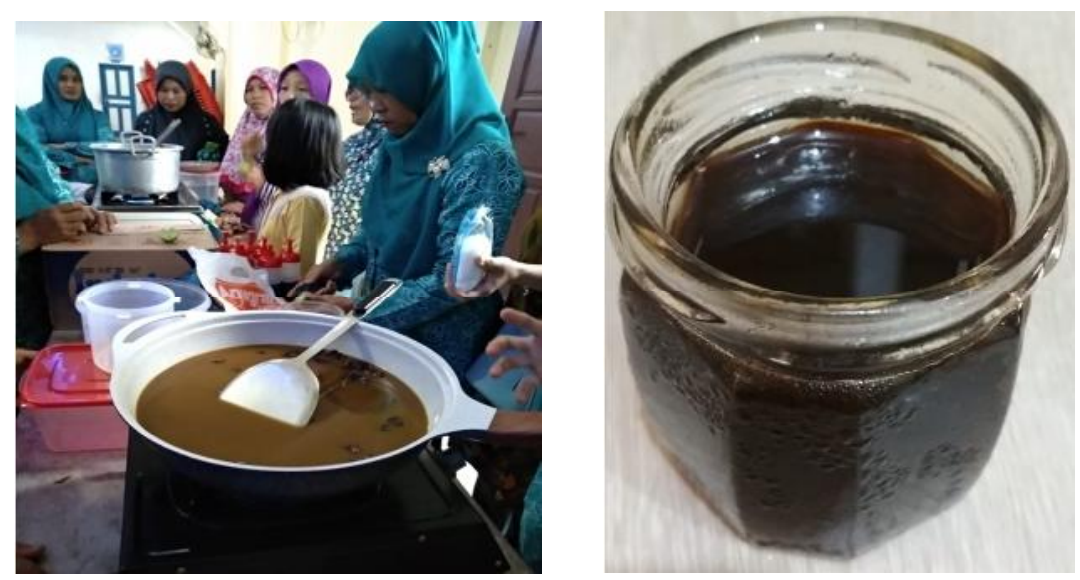

Gambar 9. Kecap berbahan dasar ikan dan penambahan bumbu-bumbu alami dengan metode pemasakan menghasilkan kecap ikan bebas bahan pengawet

\section{Evaluasi Keberhasilan Kegiatan}

Setelah dilakukan pelatihan dalam kegiatan pengabdian masyarakat ini, selanjutnya adalah tahap evaluasi dari keseluruhan kegiatan. Adapun cara evaluasinya adalah dengan membandingkan pengetahuan dan pemahaman peserta sebelum dan sesudah pelatihan baik untuk sesi praktek langsung maupun sesi materi. Peserta memahami bahwa ikan dapat diolah dengan berbagai metode pengolahan tidak hanya sebagai lauk pelengkap makanan tetapi dapat dijadikan produk bahan pangan yang memiliki nilai ekonomis tinggi dan bisa menambah pendapatan keluarga. Secara umum menunjukkan terjadi peningkatan pengetahuan peserta, dimana ditunjukkan pada saat praktek semua peserta dapat melakukan dengan mandiri, memahami biaya-biaya yang berhubungan dengan kewirausahawan, mampu menjelaskan kembali saat diberi pertanyaan dalam sesi diskusi atau tanya jawab. Adapun kriteria dan indikator keberhasilan kegiatan pengabdian masyarakat ini dapat lihat pada Tabel 2.

Tabel 2. Indikator Keberhasilan Kegiatan

\begin{tabular}{|l|l|l|}
\hline No. & \multicolumn{1}{|c|}{ Kriteria } & \multicolumn{1}{c|}{ Indikator } \\
\hline 1. & Tingkat partisipasi & $\begin{array}{l}\text { Kegiatan pelatihan dipenuhi peserta karena tingkat } \\
\text { kehadiran mencapai 100\% sesuai dengan jumlah undangan } \\
\text { yang disebarkan. }\end{array}$ \\
\hline 2. & $\begin{array}{l}\text { Tingkat pemahaman ibu- } \\
\text { ibu peserta terhadap } \\
\text { materi pelatihan }\end{array}$ & $\begin{array}{l}\text { Tercermin terjadi proses peningkatan pemahaman tentang } \\
\text { materi kecap ikan dan mampu menentukan harga jual } \\
\text { hingga mendapatkan untung. Ibu-ibu peserta aktif dalam } \\
\text { diskusi, tanya jawab menyampikan ide dan mampu } \\
\text { mempraktikkan dengan baik. Peserta sangat serius dan } \\
\text { antusias mengikuti dari awal acara hingga selesai selama } \\
\text { dua hari }\end{array}$ \\
\hline 3. & Dampak penyuluhan & $\begin{array}{l}\text { Peserta mampu mempraktikkan cara membuat kecap ikan, } \\
\text { meracik dan mencampur bahan-bahan yang diperlukan } \\
\text { dalam membuat kecap ikan, mampu memahami biaya-biaya }\end{array}$ \\
\hline
\end{tabular}




\begin{tabular}{|l|l|l|}
\hline & & $\begin{array}{l}\text { dalam pembuatan produk kecap ikan dan mempunyai ide } \\
\text { tentang cara pemasaran untuk produk yang dihasilkan. }\end{array}$ \\
\hline 4. & Kesesuaian materi & $\begin{array}{l}\text { Menurut pendapat peserta materi pelatihan sangat up to } \\
\text { date. Cara penyampaian yang lugas dan komunikatif } \\
\text { memudahkan dan menarik peserta untuk mengikuti dan } \\
\text { memahami materi kecap ikan baik dalam teori, bahan-bahan } \\
\text { pembuatan hingga harga jual di pasaran. }\end{array}$ \\
\hline
\end{tabular}

Susunan acara yang dibuat sangat fleksibel dan pemberian materi yang tepat baik secara waktu maupun tempat dirasakan sangat mendukung kegiatan, dimana peserta mempunyai banyak waktu untuk mengikuti pelatihan ini dengan nyaman sampai tuntas.

\section{Luaran Yang Dicapai}

Luaran yang dicapai dari hasil kegiatan pengabdian masyarakat ini, dapat berupa laporan hasil kegiatan pengabdian masyarakat, publikasi di jurnal nasional, peningkatan daya saing seperti halnya ikan dapat dibuat menjadi produk pendamping makanan maupun pelengkap masakan, perbaikan tata nilai masyarakat seperti halnya pemanfaatan produk berbahan dasar perikanan selain memberikan kesehatan bagi tubuh juga menambah perekonomian keluarga, dan hasil produk yang telah dibuat menambah semangat ibu-ibu peserta untuk membentuk kelompok usaha berbadan hukum dibawah naungan Universitas Dharmawangsa, dengan salah satu kegiatannya adalah membuka peluang usaha berbahan dasar produk perikanan.

\section{SIMPULAN}

Dari hasil kegiatan yang telah dilakukan maka dapat ditarik kesimpulan bahwa :

1. Pengetahuan, pemahaman dan ketrampilan ibu-ibu peserta pelatihan di Desa Tanjung Selamat dalam merancang dan membuat produk hasil olahan ikan meningkat.

2. Ibu-ibu rumah tangga peserta pelatihan yang masih menganggur sangat termotivasi menjadi wirausaha baru dibidang perikanan

3. Hasil diversifikasi produk bahan pangan perikanan ini dapat dijadikan alternatif salah satu sumber penghasilan sehingga dapat meningkatkan perekonomian keluarga.

\section{DAFTAR RUJUKAN}

DKBU. 2011. Industri Kecap Ikan. Jakarta Pusat.

https://www.google.com/url?sa=t\&rct=j\&q=\&esrc=s\&source=web\&cd=1\&ved=2ahUK

Ewj2v7mdsN3fAhUOSI8KHfkbDTQQFjAAegQIBxAB\&url=https\%3A\%2F\%2Fwww. 
bi.go.id\%2Fid\%2Fumkm\%2Fkelayakan\%2Fpola-

pembiayaan\%2Findustri\%2FPages\%2Fkecapikan_19042011.aspx\&usg=AOvVaw01n5 G6B2zZT-hhYJ8wSR2p.

Ma'ruf, Widodo Farid et al. 2015. Petunjuk Teknis Teknologi Sederhana Pengolahan Bagi Masyarakat Pesisir.

Siswi Astuti, Eko Edy Susanto, Ertin Lestari. 2015. “Kelompok Nelayan Usaha Kecap Dari Limbah Ikan Laut Dengan Teknologi Hidrolisis Enzimatis Di Desa Watukarung Pacitan.” In Peningkatan Daya Saing Teknologi Nasional Menyongsong MEA 2015, ed. Sanny Andjar Sari Fourry Handoko. Malang: LPPM - Insitut Teknologi Nasional, 471.

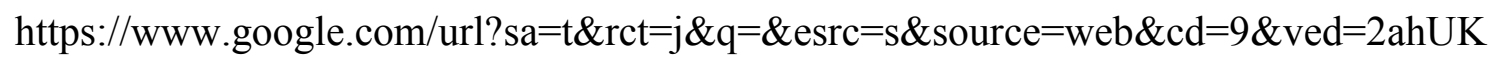
EwipxpS_qt3fAhXKQ48KHbPBB0IQFjAIegQICRAC\&url=https\%3A\%2F\%2Flppm.itn .ac.id\%2Fwebmin\%2Fassets\%2Fuploads\%2Flf\%2FLF201701180051.pdf\&usg=AOvVa w37cL9p0ps7CjVAzbz2b-wP. 